\title{
Determinan Yang Berhubungan Dengan Kejadian Penyakit Typus Pada Masyarakat Di Desa Tanjung Hulu Kecamatan Sepauk Kabupaten Sintang Tahun 2015
}

\section{Determinant Related With The Incidence Of Disease Typus In Public In The Village Tanjung Hulu Districts Sepauk Sintang Year 2015}

\section{ABIL RUDI}

\section{Program Studi Kesehatan Masyarakat Sekolah Tinggi Ilmu Kesehatan Kapuas Raya Sintang}

\section{ABSTRAK}

Penyakit typus merupakan penyakit infeksi yang di sebabkan oleh bakteri salmonella thyposa. Terjadinya penyakit typus disebabkan oleh penderita mengkonsumsi makanan dan minuman yang terkontaminasi oleh bakteri salmonella thyposa. Kejadian penyakit typus dipengaruhi oleh lingkungan yang kurang bersih dan kebiasaan masyarakat membuang sampah sembarangan. Penelitian ini bertujuan untuk menjelaskan faktor yang berhubungan dengan kejadian penyakit typus pada penderita di Desa Tanjung Hulu Kecamatan Sepauk Sintang tahun 2015. Penelitian ini merupakan penelitian kuantitatif dengan rancangan cross sectional. Sampel penelitian menggunakan total sampling yaitu sebanyak 62 responden dengan cara pengumpulan data yaitu wawancara dan pengamatan yang berpedoman pada kuesioner. Analisis data mengunakan analisis univariat dan bivariat. Hasil uji statistik menunjukkan bahwa variabel yang berhubungan dengan kejadian penyakit typus adalah jenis kelamin $(P$ value $=0,047)$, pengetahuan $(P$ value $=$ $0,001)$, sikap $(P$ value $=0,029)$ dan praktek $(P$ value $=0,012)$. Oleh karena itu, disarankan kepada Dinas Kesehatan dan Pusat Kesehatan masyarakat untuk meningkatkan program promosi kesehatan di masyarakat terkait pencegahan penyakit typus.

\section{Kata Kunci : penyakit typus, masyarakat}

\section{ABSTRACK}

Typus disease is infections desase caused by bacteria salmonella thyposa. Typus disease caused by people consuming foods and beverages contaminated by bacteria salmonella thyposa. Typus disease incidence is influenced by a less clean environment and people's habits of littering. This study aims to explain the risk related with incidence of disease typus in patients in the village Tanjung hulu Districts Sepauk Sintang year 2015. This research is using quantitative method with cross sectional design. Total sample using sampling as many as 62 respondents and using data collecting method by interview and observations based on the questionnaire. Analysis of the data using univariate and bivariate analyzes. The statistic test results showed that the variable related with the incidence of disease typus is sex ( $P$ value $=$ $0,047)$, level of knowledge $\quad(P$ value $=$ $0,001)$, attitude $(P$ value $=0,029)$ and practice $(P$ value $=0,012)$. Therefore, it is suggested to the Health Departments and Public Health Centers to improve health promotion programs related disease prevention typus.

\section{Keywords : typus disease, public}

\section{Pendahuluan}

Thypus Abdominalis merupakan penyakit infeksi akut pada usus halus dengan gejala demam satu minggu atau lebih dan disertai gangguan pada saluran pencernaan dengan atau tanpa gangguan kesadaran. Gangguan pencernaan yang terjadi adalah bibir kering, lidah kotor, selaput putih, ada perut kembung nyeri tekan. Pada umumnya diare, kesadaran menurun ringan sampai berat umumnya apatis penurunan kesadaran (Rampengan, 2006).

Badan Kesehatan Dunia (WHO) memperkirakan jumlah kasus demam tifoid, Diseluruh dunia mencapai $16-33$ juta dengan 500-600 ribu kematian setiap tahunnya. Typus merupakan penyakit infeksi menular yang dapat terjadi pada anak maupun penderita. Anak merupakan yang paling rentan terkena demam tifoid,walaupun gejala yang dialami anak lebih ringan dari pada penderita. Dihampir semua daerah endemik, insiden typusbanyak terjadi pada anak usia 5-19 tahun (Husan, 2011 dalam Pratama E, 2012). 
Surverlans Departemen Kesehatan RI, frekuensi kejadian Demam Thypoid di Indonesia pada tahun 1990 sebesar 9,2 dan pada tahun 1994 terjadi peninggkatan frekuensi menjadi 15,4 per 10.000 penduduk. Dari survey berbagai rumah sakit di Indonesia dari tahun 1981 sampai dengan 1986 memperlihatkan peningkatan jumlah penderita sekitar 35,8\% yaitu dari 19,596 menjadi 26,606 kasus (Aru W. Sudoyo, 2009).

Penyakit tifus atau yang dikenal thypus abdominalis mewabah di Kota Pontianak Provinsi Kalimantan Barat. Kepala Dinas Kesehatan Kota Pontianak, Multi Juto Bhatarendo mengungkapkan hingga minggu ke 11 sepanjang tahun 2011, penderita tifus menembus angka 200 kasus. Jumlah ini melebihi penyakit demam berdarah yang hanya dua kasus.

Berdasarkan dari data kasus penyakit yang ada di Dinas Kesehatan Kabupaten Sintang pada tahun 2013 terdapat 5307 kasus typus, sedangakan pada tahun 2014 terjadi peningkatan kasus typus sebanyak 6823 kasus.

Hasil data kasus penyakit typus di Puskesmas Sepauk pada tahun 2015 dari bulan januari sampai bulan maret pada tingkatan umur 1-4 tahun berjumlah 35 kasus,umur 5-9 tahun berjumlah 78 kasus, umur 10-14 tahun berjumlah 76 kasus, umur 15-19 tahun berjumlah 51 kasus, 20-44 tahun berjumlah 181 kasus, umur 45-54 tahun berjumlah 50 kasus, umur 55-59 tahun berjumlah 16 kasus, umur 60-69 tahun berjumlah 4 kasus dan umur diantara 22-44 tahun di Desa Tanjung Hulu Kecamatan Sepauk Sintang.

Penelitian dilaksanakan setelah memperoleh persetujuan dari Ketua Sekolah Tinggi Ilmu Kesehatan (STIKes) Kapuas Raya Sintang dan ijin penelitian. Penelitian dimula dari
$>70$ tahun berjumlah 4 kasus (Pukesmas Sepauk, 2014).

Hasil Studi pendahuluan pada penderita di Desa Tanjung Hulu Kecamatan Sepauk Kabupaten Sintang, tentang kejadian penyakit typus bahwa dari 20 penderita sebanyak 10 penderita mengalami penyakit typus secara mendadak dan 10 penderita mengalami peyakit typus berulang. Sebanyak 15 penderita tidak tahu penyebab penyakit typus dan 5 penderita hanya mengetahui gejala penyakit typus. Selain itu juga, hasil observasi di sekitar lingkungan tempat tinggal penderita terdapat tumpukan sampah dan parit rumah yang kotor serta terdapat genangan air.

\section{Metode}

Penelitian ini merupakan penelitian kuantitatif dengan rancangan cross sectional yaitu suatu rancangan penelitian dimana variabel independen dan variabel dependen diukur pada waktu penelitian berlangsung yang dapat menjelaskan suatu hubungan (Hidayat, 2007). Penelitian ini dilakukan pada masyarakat yang pernah menderita penyakit typus yang berusia

Penelitian dilaksanakan setelah memperoleh persetujuan dari Ketua Sekolah Tinggi Ilmu Kesehatan (STIKes) Kapuas Raya Sintang dan ijin penelitian. Penelitian dimula dari penyusunan proposal sampai dengan penyusunan laporan penelitian yang dilaksanakan pada bulan April-Oktober 2015. Jumlah sampel dalam penelitian ini sama dengan total populasi (total sampling) sebanyak 62 orang. penyusunan proposal sampai dengan penyusunan laporan penelitian yang dilaksanakan pada bulan April-Oktober 2015. Jumlah sampel dalam penelitian ini sama dengan total populasi (total sampling) sebanyak 62 orang.

\section{Hasil}

Hasil univariat di dapatkan sebagai berikut :

Tabel 1.1 Distribusi frekuensi kejadian penyakit typus pada penderita di Desa Tanjung Hulu Kecamatan Sepauk Kabupaten Sintang Tahun 2015

\begin{tabular}{ccc}
\hline Kejadian penyakit typus & Jumlah & Persentase \\
\hline Berulang & 35 & $56.5 \%$ \\
Tidak berulang & 27 & $43.5 \%$ \\
\hline Total & 62 & $100 \%$ \\
\hline
\end{tabular}


Tabel 1.1 didapatkan bahwa kejadian penyakit typus pada penderita di Desa Tanjung Hulu Kecamatan Sepauk Kabupaten Sintang tahun
2015 yang paling tinggi adalah mengalami kejadian penyakit typus berulang sebanyak 35 responden $(56,5 \%)$.

Tabel 1.2. Distribusi Frekuensi Karakteristik Responden di Desa Tanjung Hulu Kecamatan Sepauk Kabupaten Sintang Tahun 2015

\begin{tabular}{|c|c|c|c|c|}
\hline Karakteristik Responden & $\mathbf{n}$ & Persentase & P value & OR \\
\hline $\begin{array}{l}\text { Jenis Kelamin } \\
\text { Laki - laki } \\
\text { Perempuan }\end{array}$ & $\begin{array}{l}33 \\
29\end{array}$ & $\begin{array}{l}53.2 \% \\
46.8 \%\end{array}$ & 0.047 & 3.258 \\
\hline $\begin{array}{l}\text { Pendidikan } \\
\text { Pendidikan rendah } \leq \text { SLTA } \\
\text { Pendidikan tinggi }>\text { SLTA }\end{array}$ & $\begin{array}{c}53 \\
9\end{array}$ & $\begin{array}{l}85.5 \% \\
14.5 \%\end{array}$ & 0.160 & 0.048 \\
\hline $\begin{array}{l}\text { Tingkat pengetahuan } \\
\text { Rendah } \\
\text { Tinggi }\end{array}$ & $\begin{array}{l}37 \\
25\end{array}$ & $\begin{array}{l}59.7 \% \\
40.3 \% \\
\end{array}$ & 0.035 & 1.354 \\
\hline $\begin{array}{l}\text { Sikap } \\
\text { Negatif } \\
\text { Positif }\end{array}$ & $\begin{array}{l}34 \\
28\end{array}$ & $\begin{array}{l}54.8 \% \\
45.3 \%\end{array}$ & 0.029 & 1.238 \\
\hline $\begin{array}{l}\text { Praktik } \\
\text { Kurang baik } \\
\text { Baik }\end{array}$ & $\begin{array}{l}34 \\
28\end{array}$ & $\begin{array}{l}54.8 \% \\
45.2 \%\end{array}$ & 0.012 & 2.115 \\
\hline $\begin{array}{l}\text { Peran Tenaga Kesehatan } \\
\text { Kurang baik } \\
\text { Baik }\end{array}$ & $\begin{array}{l}32 \\
30\end{array}$ & $\begin{array}{l}51.6 \% \\
48.4 \%\end{array}$ & 0.823 & 0.279 \\
\hline
\end{tabular}

Berdasarkan tabel 1.2 dapat dilihat bahwa variabel jenis kelamin, tingkat pengetahuan, sikap dan praktik memiliki hubungan yang signifikan $(p$ value $<0,05)$ dengan kejadian penyakit typus pada masyarakat usia 22-44 tahun di Desa Tanjung Hulu Kecamatan Sepauk Kabupaten Sintang tahun 2015. Uji

\section{Pembahasan}

\section{Variabel kejadian penyakit typus}

Berdasarkan hasil penelitian pada responden tentang kejadian penyakit typus pada masyarakat usia 22-44 tahun, bahwa dari 62 responden didapatkan sebanyak 35 $(56.5 \%)$ responden mengalami penyakit typus berulang.

Penyakit typus merupakan salah satu penyakit yang sering terjadi di masyarakat. Kejadian penyakit typus pada masyarakat usia 22-44 tahun di akibatkan karena perilaku hidup bersih dan sehat yang tidak optimal. Masyarakat usia 22-44 tahun di Desa Tanjung Hulu Kecamatan Sepauk Kabupaten Sintang lebih sering mengalami penyakit typus yang berulang, hal ini berdasarkan hasil penelitian bahwa dari statistik menunjukkan bahwa variabel pendidikan dan peran tenaga kesehatan tidak memiliki hubungan dengan kejadian penyakit typus pada masyarakat usia 22-44 tahun di Desa Tanjung Hulu Kecamatan Sepauk Kabupaten Sintang Tahun 2015.

kebanyakan masyarakat Desa Tanjung Hulu Kecamatan Sepauk Kabupaten Sintang membuang sampah sembarangan, adanya genangan air di samping rumah, parit rumah yang kotor, sering mengkonsusmsi air minum yang tidak pernah di masak sampai mendidih yang dapat menyebabkan kejadian penyakit typus pada usia 22-44 tahun.

Kejadian penyakit typus pada masyarakat usia 22-44 tahun dikarenakan perilaku masyarakat yang tidak memperhatikan faktor-faktor penyebab kejadian penyakit typus tersebut. Selain itu juga, bahwa kejadian penyakit typus berulang diakibatkan oleh pengetahuan yang rendah dan sikap yang negatif dalam melakukan pencegahan kejadian penyakit typus. 
Typus adalah penyakit sistemik akut yang mempunyai karakteritik demam, sakit kepala dan ketidakenakan abdomen berlangsung lebih kurang 3 minggu yang juga disertai gejala-gejala perut pembesaran limpa dan erupsi kulit. Typus (termasuk para-tifoid) disebabkan oleh kuman Salmonella typhi, $S$ paratyphi $A, \quad S$ paratyphi $B$ dan $S$ paratyphi $C$. Jika penyebabnya adalah $\mathrm{S}$ paratyphi, gejalanya lebih ringan dibanding dengan yang disebabkan oleh S typhi (Rampengan, 2006).

\section{Variabel jenis kelamin responden}

Hasil analisis univariat dari 62 responden ditemukan bahwa jenis kelamin responden pada masyarakat usia 22-44 tahun yang paling banyak adalah berjenis kelamin laki-laki sebanyak 33 (53.2 \%) responden, sedangkan yang sedikit adalah berjenis kelamin perempuan sebanyak 29 $(46.8 \%)$ responden. Hasil analisis bivariat ditemukan bahwa ada $23(69.7 \%)$ dari 35 responden berjenis kelamin laki-laki yang mengalami penyakit typus berulang pada masyarakat usia 22-44 tahun di Desa Tanjung Hulu Kecamatan Sepauk Kabupaten Sintang. Hasil uji statistik ditemukan bahwa ada hubungan yang signifikan antara jenis kelamin dengan kejadian penyakit typus pada masyarakat usia 22-44 tahun di Desa Tanjung Hulu Kecamatan Sepauk Kabupaten Sintang.

Perbedaan jenis kelamin mengindikasikan adanya perbedaan dalam melakukan aktifitas atau kebiasaan. Berdasarkan penelitian bahwa jenis kelamin laki-laki lebih banyak mengalami penyakit typus berulang, dibandingkan berjenis kelamin perempuan. Hal ini didasari karena laki-laki lebih banyak melakukan kebiasaan sebelum makan tidak pernah mencuci tangan dan kurang memperhatikan kebersihan makanan yang di makan. Sedangkan, perempuan akan lebih konsentrasi dalam menjaga kebersihan makanan.

Selain itu juga, bahwa kebanyakan responden yang diteliti adalah berjenis kelamin laki-laki, dengan demikian bahwa tindakan yang dilakukan oleh laki-laki dalam sehari-hari akan lebih tinggi mengalami penyakit typus berulang pada usia 22-44 tahun, seperti membuang sampah sembarangan, tidak pernah mencuci tangan sebelum makan, tidak pernah menutup makanan yang akan dimakan dan mengkonsumsi minuman yang tidak di masak.

Hasil penelitian ini sejalan dengan hasil penelitian oleh Sunson Somantri (2013), penelitian berjudul : hubungan hygiene makanan dengan demam typhoid di Rumah Sakit Umum Daerah Majalaya Kecamatan Paseh Kebupaten Bandung tahun 2013. Hasil penelitian menemukan bahwa ada hubungan antara jenis kelamin responden dengan demam typhoid di Rumah Sakit Umum Majalaya Kecamatan Paseh Kabupaten Bandung tahun 2013.

Perbedaan jenis kelamin tidak memiliki perbedaan yang signifikan dalam kejadian penyakit typus. Hubungan antara jenis kelamin dengan kejadian penyakit typus bahwa tidak ada bukti nyata yang menunjukkan perbedaan antara laki-laki dan perempuan dalam kejadian penyakit typus. Namun, Perbedaan cenderung pada faktor perilaku individu dalam melakukan perilaku hidup bersih dan sehat (Soegeng Soegijanto, 2006).

\section{Variabel pendidikan responden}

Hasil analisis univariat dari 62 responden ditemukan bahwa pendidikan responden tentang kejadian penyakit typus pada masyarakat usia 22-44 tahun yang paling banyak adalah pendidikan rendah $\leq$ SLTA sebanyak $53(85.5 \%)$ responden. Hasil analisis bivariat ditemukan bahwa ada $32(60.4 \%)$ dari 35 responden dengan pendidikan rendah yang mengalami penyakit typus berulang pada masyarakat usia 22-44 tahun di Desa Tanjung Hulu Kecamatan Sepauk Kabupaten Sintang. Hasil uji statistik menemukan bahwa tidak ada hubungan yang signifikan antara pendidikan dengan kejadian penyakit typus pada masyarakat usia 22-44 tahun di Desa Tanjung Hulu Kecamatan Sepauk Kabupaten Sintang. 
Berdasarkan hasil penelitian bahwa pendidikan rendah lebih banyak dibandingkan pendidikan tinggi. Analisis lebih lanjut bahwa pendidikan responden yang rendah lebih banyak mengalami kejadian penyakit typus berulang, dibandingkan pendidikan responden yang tinggi. Responden berpendidikan rendah lebih banyak melakukan tindakan yang kurang bersih dan sehat yang menyebabkan kejadian penyakit typus berulang pada masyarakat di Desa Tanjung Hulu Kecamatan Sepauk Kabupaten Sintang. Demikian juga bahwa pendidikan tinggi lebih mengutamakan melakukan tindakan bersih. Adapun jenis tindakan yang menyebabkan kejadian penyakit typus berulang adalah membuang sampah sembarangan, adanya genangan air di samping rumah, parit rumah yang kotor, sering mengkonsusmsi air minum yang tidak pernah di masak sampai mendidih pada masyarakat usia 22-44 tahun di Desa Tanjung Hulu Kecamatan Sepauk Kabupaten Sintang Tahun 2015.

Hasil penelitian ini sejalan dengan penelitian yang dilakukan oleh Deby Jusyanto (2012), penelitian berjudul : hubungan personal hygiene dengan kejadian typus abdominalis di Wilayah Kerja Puskesmas Lepo-Lepo Kota Kendari Tahun 2012. Hasil penelitian menemukan bahwa ada hubungan antara pendidikan responden dengan kejadian penyakit typus pada masyarakat usia 22-44 tahun di Desa Tanjung Hulu Kecamatan Sepauk Kabupaten Sintang.

Pendidikan adalah suatu proses yang akan membentuk perilaku dan kemampuan baru. Dengan demikian seseorang yang berpendidikan akan mempunyai pengetahuan dan wawasan yang lebih luas. Orang yang berpendidikan tinggi akan berfikir sejauhmana keuntungan yang mungkin akan mereka peroleh dari gagasan tersebut, individu yang berpendidikan tentu akan banyak memberikan perubahan terhadap apa yang mereka lakukan dimasa lalu, ini berarti tingkat pendidikan seseorang akan mempengaruhi tingkat pengetahuannya. Pendidikan formal sebenarnya membentangkan harapan tentang tingkat dan jenis perubahan tingkah laku sasaran pendidikan, antara lain dengan perubahan pengetahuan, sikap dan kemampuan mereka. Pendidikan formal yang pernah ditempuh oleh sebagian besar individu menjadi salah satu faktor predisposing yang memberikan andil bagi inddividu agar lebih mudah dalam memahami dan mengerti tentang perilaku hidup bersih dan sehat (Notoatmodjo, S, 2005).

\section{Variabel tingkat pengetahuan responden}

Hasil analisis univariat dari 62 responden ditemukan bahwa tingkat pengetahuan responden tentang kejadian penyakit typus pada masyarakat usia 22-44 tahun yang paling banyak adalah tingkat pengetahuan rendah sebanyak 37 (59.7\%) responden. Hasil analisis bivariat ditemukan bahwa ada $22(59.5 \%)$ dari 35 responden dengan tingkat pengetahuan rendah yang mengalami penyakit typus berulang pada masyarakat usia 22-44 tahun di Desa Tanjung Hulu Kecamatan Sepauk Kabupaten Sintang. Hasil uji statistik menemukan bahwa ada hubungan yang signifikan antara tingkat pengetahuan dengan kejadian penyakit typus pada masyarakat usia 22-44 tahun di Desa Tanjung Hulu Kecamatan Sepauk Kabupaten Sintang.

Berdasarkan hasil penelitian bahwa responden dengan tingkat pengetahuan rendah lebih banyak dibandingkan dengan tingkat pengetahuan tinggi. Hal ini dikarenakan bahwa responden dengan tingkat pengetahuan yang rendah lebih banyak melakukan tindakan yang kurang bersih dan sehat dengan demikian bawah responden belum tahu cara melakukan pola hidup yang bersih dan sehat pada masyarakat usia 22-44 tahun di Desa Tanjung Hulu Kecamatan Sepauk Kabupaten Sintang.

Hasil penelitian ini sejalan dengan penelitian yang dilakukan oleh Deby Jusyanto (2012), penelitian berjudul : Hubungan Personal Hygiene Dengan Kejadian Typus Abdominalis Di Wilayah Kerja Puskesmas Lepo-Lepo Kota Kendari Tahun 2012. Hasil penelitian menemukan 
bahwa ada hubungan antara pengetahuan dengan kejadian Typus Abdominalis. Demikian juga, penelitian yang di lakukan oleh Sunson Somantri (2013), penelitian berjudul : Hubungan Hygiene Makanan Dengan Demam Typhoid Di Rumah Sakit Umum Daerah Majalaya Kecamatan Paseh Kebupaten Bandung tahun 2013. Hasil penelitian menemukan bahwa ada hubungan antara pengetahuan dengan demam typoid Di Rumah Sakit Umum Daerah Majalaya Kecamatan Paseh Kebupaten Bandung tahun 2013.

Menurut L.Green dalam Soekidjo Notoatmodjo (2012), menyatakan bahwa pengetahuan merupakan salah satu faktor predisposisi dalam pembentukan perilaku. Sedangkan menurut Soekidjo Notoatmodjo (2005), menyatakan bahwa pengetahuan merupakan hasil dari tahu dan ini terjadi setelah orang melakukan penginderaan terhadap suatu objek tertentu.

\section{Variabel sikap responden}

Hasil analisis univariat dari 62 responden ditemukan bahwa sikap responden tentang kejadian penyakit typus pada masyarakat usia 22-44 tahun yang paling banyak adalah bersikap negatif sebanyak 34 (54.8 \%) responden. Hasil analisis bivariat ditemukan bahwa ada 20 $(58.8 \%)$ dari 35 responden dengan sikap negatif yang mengalami penyakit typus berulang pada masyarakat usia 22-44 tahun di Desa Tanjung Hulu Kecamatan Sepauk Kabupaten Sintang. Hasil uji statistik menemukan bahwa ada hubungan yang signifikan antara sikap dengan kejadian penyakit typus pada masyarakat usia 22-44 tahun di Desa Tanjung Hulu Kecamatan Sepauk Kabupaten Sintang.

Selain pengetahuan, sikap merupakan domain yang penting dalam terbentuknya tindakan seseorang. Sikap yang dimiliki oleh responden bukan hanya tahu menyebutkan bagaimana harus bersikap, melainkan harus tumbuhnya sikap itu sendiri untuk berperilaku atau melakukan sesuatu kearah yang lebih baik. Dengan demikian, bahwa sikap merupakan kesediaan untuk bertindak atau predisposisi tindakan suatu perilaku. Berdasarkan hasil penelitian bahwa sikap negatif lebih banyak dibandingkan dengan sikap positif. Dengan demikian, bahwa sikap yang negatif berpengaruh pada kejadian penyakit typus pada masyarakat usia 22-44 tahun di Desa Tanjung Hulu Kecamatan Sepauk Kabupaten Sintang.

Hasil penelitian ini sejalan dengan penelitian yang dilakukan oleh Deby Jusyanto (2012), penelitian berjudul : Hubungan Personal Hygiene Dengan Kejadian Typus Abdominalis Di Wilayah Kerja Puskesmas Lepo-Lepo Kota Kendari Tahun 2012. Hasil penelitian menemukan bahwa ada hubungan antara sikap dengan kejadian Typus Abdominalis. Demikian juga, penelitian yang di lakukan oleh Sunson Somantri (2013), penelitian berjudul : Hubungan Hygiene Makanan Dengan Demam Typhoid Di Rumah Sakit Umum Daerah Majalaya Kecamatan Paseh Kebupaten Bandung tahun 2013. Hasil penelitian menemukan bahwa ada hubungan antara sikap dengan demam typoid Di Rumah Sakit Umum Daerah Majalaya Kecamatan Paseh Kebupaten Bandung tahun 2013.

Sikap merupakan reaksi atau respon yang masih tertutup dari seseorang terhadap suatu stimulus atau objek (Notoatmodjo, S, 2012). Demikian juga menurut Seokidjo Notoatmodjo (2010), menyatakan bahwa sikap adalah respon tertutup seseorang terhadap stimulus atau objek tertentu, yang sudah melibatkan faktor pendapat dan emosi yang bersangkutan (senang-tidak senang, setuju-tidak setuju, baik-tidak baik). Sikap merupakan reaksi atau respon yang masih tertutup dari seseorang terhadap suatu stimulus atau objek. Sedangkan menurut Soekidjo Notoatmodjo (2005), menyatakan bahwa manifestasi sikap tidak dapat dilihat secara langsung tetapi harus ditafsirkan terlebih dahulu dari perilaku yang tertutup. sikap merupakan kesediaan untuk bertindak dan belum merupakan suatu tindakan sehingga sikap merupakan predisposisi tindakan dari suatu perilaku.

\section{Variabel praktik responden}

Hasil analisis univariat dari 62 responden ditemukan bahwa praktik 
responden tentang kejadian penyakit typus pada masyarakat usia 22-44 tahun yang paling banyak adalah praktik kurang baik sebanyak 34 (54.8 \%) responden. Hasil analisis bivariat ditemukan bahwa ada 22 $(64.7 \%)$ dari 35 responden dengan praktik kurang baik yang mengalami penyakit typus berulang pada masyarakat usia 22-44 tahun di Desa Tanjung Hulu Kecamatan Sepauk Kabupaten Sintang. Hasil uji statistik menemukan bahwa ada hubungan yang signifikan antara praktik dengan kejadian penyakit typus pada masyarakat usia 22-44 tahun di Desa Tanjung Hulu Kecamatan Sepauk Kabupaten Sintang.

Berdasarkan hasil penelitian bahwa praktik kurang baik responden yang paling banyak mengalami kejadian penyakit typus pada masyarakat usia 22-44 tahun di Desa Tanjung Hulu Kecamatan Sepauk Kabupaten Sintang tahun 2015. Tindakan responden yang kurang baik dalam melakukan pencegahan penyakit typus seperti jarang mencuci tangan sebelum makan, air yang di konsumsi tidak pernah masak sampai mendidih dan membuang sampah sembarangan.

Hasil penelitian ini sejalan dengan penelitian yang dilakukan oleh Deby Jusyanto (2012), penelitian berjudul : Hubungan Personal Hygiene Dengan Kejadian Typus Abdominalis Di Wilayah Kerja Puskesmas Lepo-Lepo Kota Kendari Tahun 2012. Hasil penelitian menemukan bahwa ada hubungan antara praktik dengan kejadian Typus Abdominalis. Demikian juga, penelitian yang di lakukan oleh Sunson Somantri (2013), penelitian berjudul : Hubungan Hygiene Makanan Dengan Demam Typhoid Di Rumah Sakit Umum Daerah Majalaya Kecamatan Paseh Kebupaten Bandung tahun 2013. Hasil penelitian menemukan bahwa ada hubungan antara praktik dengan demam typoid Di Rumah Sakit Umum Daerah Majalaya Kecamatan Paseh Kebupaten Bandung tahun 2013.

Menurut Soekidjo Notoatmodjo (2010), menyatakan bahwa praktik atau tindakan merupakan praktik seseorang yang telah melakukan atau mempraktikkan sesuatu hal secara otomatis maka disebut praktik atau tindakan mekanis, praktik yang sudah berkembang yang dilakukan tidak sekedar rutinitas atau mekanisme saja, tetapi sudah dilakukan modefikasi atas perilaku yang berkualitas.

\section{Variabel peran petugas kesehatan}

Hasil analisis univariat dari 62 responden ditemukan bahwa peran tenaga kesehatan responden tentang kejadian penyakit typus pada masyarakat usia 22-44 tahun yang paling banyak adalah peran tenaga kesehatan kurang baik sebanyak 32 $(51.6 \%)$ responden. Hasil analisis bivariat ditemukan bahwa ada 19 (59.4\%) dari 35 responden dengan peran tenaga kesehatan kurang baik yang mengalami penyakit typus berulang pada masyarakat usia 22-44 tahun di Desa Tanjung Hulu Kecamatan Sepauk Kabupaten Sintang. Hasil uji statistik menemukan bahwa tidak ada hubungan yang signifikan antara peran tenaga kesehatan dengan kejadian penyakit typus pada masyarakat usia 22-44 tahun di Desa Tanjung Hulu Kecamatan Sepauk Kabupaten Sintang.

Berdasarkan hasil penelitian bahwa peran tenaga kesehatan kurang baik yang paling banyak berisiko menyebabkan kejadian penyakit typus pada masyarakat usia 22-44 tahun di Desa Tanjung Hulu Kecamatan Sepauk Kabupaten Sintang tahun 2015. Kurangnya perhatian dari tenaga kesehatan dalam melakukan pelayanan kesehatan menyebabkan masyarakat kurang memahami bagaimana cara hidup bersih dan sehat, dalam hal ini berkaitan dengan melakukan pencegahan terjadinya penyakit typus.

Hasil penelitian ini tidak sejalan penelitian yang di lakukan oleh Islawati (2014), penelitian berjudul : Faktor-Faktor Yang Mempengaruhi Kejadian Penyakit Typus Pada Pasien Yang Dirawat di Rumah Sakit Umum Sulawesi Tengah tahun 2014. Hasil penelitian menemukan bahwa ada hubungan antara peran petugas kesehatan dengan kejadian penyakit typus pada pasien yang dirawat di Rumah Sakit Umum Sulawesi Tengah tahun 2014. 
Peranan tenaga kesehatan dalam upaya kesehatan yang menekankan penyembuhan penyakit adalah sangat penting. Sebaliknya tenaga kesehatan yang menekankan masalah preventif dan promotif adalah sarjana kesehatan masyarakat yang juga sangat penting. Pengelolaan upaya kesehatan dan pembinaan bangsa yang sehat memerlukan pendekatan holistik yang lebih luas, menyeluruh, dan dilakukan terhadap masyarakat secara kolektif dan tidak individual. Tenaga kesehatan harus mampu mengajak, memotivasi dan memberdayakan masyarakat, mampu melibatkan kerja sama lintas sektoral, mampu mengelola sistem pelayanan kesehatan yang efisien dan efektif, mampu menjadi pemimpin, pelopor, pembinaan dan teladan hidup sehat. Dalam pembinaan dan pemberdayaan masyarakat yang sangat penting adalah bagaimana mengajak dan menggairahkan masyarakat untuk dapat tertarik dan bertanggungjawab atas kesehatan mereka sendiri dengan memobilisasi sumber dana yang ada pada mereka (Soegijanto, S. 2006).

\section{Kesimpulan}

Berdasarkan hasil analisa data dan pembahasan hasil penelitian maka dapat disimpulkan sebagai berikut :

1. Gambaran responden tentang kejadian penyakit typus pada masyarakat usia 22-44 tahun di Desa Tanjung Hulu Kabupaten Sintang Tahun 2015, diperoleh sebanyak 35 $(56.5 \%)$ responden mengalami kejadian penyakit typus berulang.

2. Analisis bivariat diperoleh bahwa variabel yang berhubungan dengan kejadian penyakit typus pada masyarakat usia 22-44 tahun adalah jenis kelamin, tingkat pengetahuan, sikap dan praktik. Sedangkan variabel yang tidak berhubungan dengan kejadian penyakit typus pada masyarakat usia 22-44 tahun adalah pendidikan dan peran tenaga kesehatan.

\section{Daftar Pustaka}

Aru W.Sudoyo, 2009. Buku Ajar Ilmu Penyakit dalam Edisi V jilid II. Jakarta : interna Publishing

Deby Jusyanto. 2012. Hubungan personal hygiene dengan kejadian typus

\author{
abdominalis di Wilayah Kerja \\ Puskesmas Lepo-Lepo Kota Kendari \\ Tahun 2012
}

Hidayat, A., A. 2007. Riset keperawatan dan teknik penulisan ilmiah. Jakarta: Salemba Medika

Islawati. 2014. Faktor-Faktor Yang Mempengaruhi Kejadian Penyakit Typus Pada Pasien Yang Dirawat di Rumah Sakit Umum Sulawesi Tengah tahun 2014

Notoatmodjo.S. 2005. Promosi kesehatan teori dan aplikasi. Jakarta : Rineka Cipta 2010. Promosi kesehatan : teori dan aplikasi. Jakarta : PT Rineka Cipta

Notoatmodjo.S. 2012. Metodelogi penelitian. Jakarta : PT Rineka Cipta

Puskesmas Sepauk. 2014. Data rekapitulasi penyakit typus perut. Puskesmas Sepauk Kabupaten Sintang 2014

Pratama, E. 2012. Tifus Abdominalis. http://eldepratamamehagamedan.blogsp ot.co.id. Diakses pada tanggal 09 April 2015

Rampengan. 2006. Penyakit infeksi tropik pada anak Edisi 2. Jakarta : ECG

Soegijanto, S. 2006. Kumpulan makalah penyakit tropis di Indonesia, jilid 6. Surabaya : Airlangga University Press

Sunson Somantri. 2013. Hubungan Hygiene Makanan Dengan Demam Typhoid Di Rumah Sakit Umum Daerah Majalaya Kecamatan Paseh Kebupaten Bandung tahun 2013 